\title{
Detection and Quantitative Estimation of Toxic Acrylamide Levels in Selected Potatoes Chips and French Fries from the Libyan Market Using HPLC-UV Method
}

\author{
Osama I. G. Khreit ${ }^{1 *}$, Abdulsalam Elfowiris ${ }^{2}$, Abdulrahman A. Aljali ${ }^{1}$ and Omukalthum \\ Abduljalil $^{3}$ \\ ${ }^{1}$ Department of Basic Medical Veterinary Sciences, Faculty of Veterinary Medicine, Omar Al- \\ Mukhtar University, Al-Bayda, Libya \\ ${ }^{2}$ Department of Pharmacology and Toxicology, Faculty of Pharmacy, Omar AL-Mukhtar Uni- \\ versity, Al-Bayda, Libya \\ ${ }^{3}$ ALMukhtar Centre of Research, Consultations, Technique Services and training, Omar AL- \\ Mukhtar University, Al-Bayda, Libya
}

Received: 18 December 2020. / Accepted: .15 April 2021

Doi: https://doi.org/10.54172/mjsc.v36i2.39

\begin{abstract}
Acrylamide is a potential health hazardous compound occurring in baked and fried food as a result of excessive dry heating during the preparation and/or processing of foods. Exposure to a high level of acrylamide may cause cancer, neurotoxicity, and mutagenicity. In this study, an isocratic reversed-phase high-performance liquid chromatographic (HPLC) method using a C18 column was used for the determination of acrylamide in selected food. The mobile phase consisted of $0.1 \%$ formic acid in water: acetonitrile (98:02), and the flow rate was $1.0 \mathrm{~mL}$ $\min ^{-1}$, elution was monitored at $200 \mathrm{~nm}$. Validation in selected conditions showed that the chosen method is sensitive, selective, precise, and reproducible with a linear detector response for the determination of acrylamide. The limit of detection (LOD), and the limit of quantification (LOQ), were achieved at $0.41 \mu \mathrm{g} \mathrm{mL}^{-1}$ and $1.25 \mu \mathrm{g} \mathrm{mL} \mathrm{L}^{-1}$ respectively. The proposed method was also applied after validation to the most popular six brands of chips and French fries available in the Libyan market. Acrylamide was extracted by a simplified extraction method avoiding cleanup by solid-phase extraction (SPE), then analyzed by HPLC-UV. The highest level of acrylamide was found in one brand of chips with a concentration of $16.33 \mu \mathrm{g} \mathrm{mL}^{-1}$, whereas only one of the French fries products analyzed exhibited an acrylamide concentration of $10.26 \mu \mathrm{gL}^{-1}$.
\end{abstract}

Keywords: Acrylamide, Cancer, Chips, French Fries, HPLC.

\section{INTRODUCTION}

Acrylamide is a vinyl monomer widely used in industrial applications and drinking water purification (Pedersen \& Olsson, 2003). It has long been known as a neurotoxic agent (Stadler \& Scholz, 2004). It is rapidly absorbed following oral administration in all species. Moreover, orally ingested acrylamide is able to reach most human tissues. It can cross the blood/placenta barrier in a human placenta in an in vitro model, as well as the blood/breast milk barrier in vivo of lactating mothers (Sorgel et al., 2002). Also, it is a natural by-product of carbohydrate-rich foods at high temperatures above $120^{\circ} \mathrm{C}$, and it is formed by a reaction between amino acid asparagine and reducing sugars such as potatoes when exposed to high temperature during the process of frying, roasting, or baking (Stadler

\footnotetext{
*Corresponding Author: ${ }^{1}$ Osama I. G. Khreit. osama.khreit@omu.edu.ly, Department of Basic Medical Veterinary Sciences, Faculty of Veteri-
} nary Medicine, Omar Al- Mukhtar University, Al-Bayda. 
\& Scholz, 2004). On the other hand, fried products with a low level of acrylamide were not a serious concern with regards to the potential health issue associated with ingested acrylamide as it is readily absorbed, metabolized, and excreted via urine. It was only considered as a contaminant in water sources (Rommens et al., 2008).

Acrylamide is considered one of the most common toxins in food containing high concentrations of hydrocarbons that have been subjected to high temperatures (Mottram et al., 2002). It is present in the daily food of most people's diet. It may be found in food products such as potato chips, fried potatoes, cornflakes, or bread. Some of these products are attractive to children and young people which makes matters worse (Altunay et al., 2016).

Many studies have shown that the average daily intake of acrylamide for adults was estimated to be in the range of 0.2 to $1.04 \mu \mathrm{g} / \mathrm{kg}$ of body weight per day (Hartmann et al., 2008; Konings et al., 2003; Mojska et al., 2010; Svensson et al., 2003). However, higher exposure is assumed in children and adolescents, reaching up to $3.4 \mu \mathrm{g} / \mathrm{kg}$ body weight daily (Vainio, 2003). The European Union has set a limit of $0.1 \mu \mathrm{g} / \mathrm{L}$ residual acrylamide in drinking water (Binet et al., 2015). Whereas FAO/WHO have agreed that the "no observed adverse effect level" (NOAEL) for acrylamide neuropathy is $0.5 \mathrm{mg} / \mathrm{kg}$ body weight/day, while that for fertility changes is four times higher than for peripheral neuropathy. The estimated average chronic human dietary intake is in the order of $1 \mu \mathrm{g} / \mathrm{kg}$ body weight/day (Kapp, 2002). Acrylamide is metabolized to form the epoxy derivative glycidamide which is conjugated with glutathione and converted into mercapturic acid as byproducts in urine, which is the primary route of acrylamide elimination in humans (Fuhr et al., 2006). Both acrylamide and glycidamide could bind covalently to nucleophilic sites of biological macromolecules. The major targets of these compounds seem to be the $\mathrm{SH}$ and $\mathrm{NH}_{2}$ groups of proteins and nucleic acid nitrogen (Fuhr et al., 2006), and its metabolites react with nucleophilic sites of blood protein haemoglobin (Hb) and form stable reaction products (adducts). Hb Adducts from acrylamide and glycidamide can be quantified to measure the level of human exposure to acrylamide (Wenzl et al., 2003).()

Epidemiological evidence on the relation between dietary acrylamide and the risk of several cancers has continued to accumulate during the last years (Khan et al., 2017). Many studies have confirmed that human exposure to acrylamide may lead to neurological effects in humans (Calleman et al., 1994). Also, experimental animals that were administered acrylamide orally experienced carcinogenic effects such as tumours of mammary glands in female rats, testicular tumours in male rats, and increased rates of tumours of the thyroid gland, central nervous system, uterus, clitoral gland, and oral tissues (Fuhr et al., 2006).

Acrylamide is classified as a Group 2A carcinogen by the International Agency for Research on Cancer (IARC). It has been demonstrated to have carcinogenic properties in animals and humans (Stadler \& Scholz, 2004; Virk-Baker et al., 2014), and it has been recognized as a carcinogen in rodents and classified as probably carcinogenic in humans (Bull et al., 1984). The mutagenicity of acrylamide was also confirmed at low concentrations in different mammalian cell lines (Robinson et al., 1984). Two separate independent studies have confirmed that acrylamide induced lung and skin tumours in mice at a dose of $2 \mathrm{mg} / \mathrm{kg}$ per day, administered in drinking water (Liu et al., 2019).

Consequently, many researchers investigating acrylamide content have mainly utilized gas chromatography-mass spectrometry (GC-MS) and liquid chromatography-mass spectrometry/mass spectrometry (LC-MS) for the determination and quantification of acrylamide 
in various foods (Elbashir et al., 2014; Galuch et al., 2019). Although, during the routine analysis of acrylamide by GC-MS, the derivatization step may usually be carried out before the clean-up step' which was found to be expensive and time-consuming (Gertz \& Klostermann, 2002; Nemoto et al., 2002). Calbiani et al. (2019) developed and validated a rapid method for the determination of acrylamide in cooked food samples by reversed-phase LC-MS coupled with electrospray ionization. A simplified extraction step with acidified water and without cleanup was developed in this method (Calbiani et al., 2019).

At present, several analytical methods are available for determining acrylamide content in snack food based on high-performance liquid chromatography (HPLC). These methods involve the extraction of acrylamide and utilized solid-phase extraction SPE cartridges for clean-up. The main advantage to use HPLC is that the removal of water after aqueous extraction is not necessary (Can \& Arli, 2014; Gokmen et al., 2005; Muthaiah et al., 2018; Oroian et al., 2015).

The objective of this study is to quantify and determine the level of acrylamide in chips and French fries collected from the Libyan market by assessing dietary acrylamide exposure and its effects on health in humans.

\section{MATERIALS AND METHODS}

Chemicals, reagents and solutions: All chemicals, analytical standards, reagents, and solvents used throughout this study were analytical grade and highly pure. Acrylamide (Purity 99.0\%) was purchased from (Novachim-Tunisia). Also, other chemicals and solvents were used, including acetonitrile (Carlo Erba Reagents S.A.S., France) with purity $99.9 \%$ (for HPLC) as a solvent; hexane $95 \%$ was purchased from (Sigma-Aldrich, Germany). Formic aid (Riedel-Dehaen AG Seelze Hannover) with purity 98-100 \%, Magnesium sulfate Anhydrous was purchased from FLUKA, Germany. Primary secondary amine (PSA) was purchased from VARIAN (USA), and Acetic Acid (96\%) was purchased from PANREAC QUIMICA (Spain). Water was obtained in-house by Water Distillation Unit.

A stock solution of acrylamide $\left(100 \mu \mathrm{g} \mathrm{mL}^{-1}\right)$ was prepared by dissolving $0.01 \mathrm{~g}$ in $100 \mathrm{~mL}$ of distilled water $\left(0.10 \mathrm{mg} \mathrm{mL}{ }^{-1}\right)$. Working standard solutions were prepared by appropriate dilution of the stock solution with distilled water $\left(2.5,5.0,10,15\right.$, and $\left.20 \mu \mathrm{g} \mathrm{mL}^{-1}\right)$.

Sample Extraction: The extraction procedure of the potato chips sample entailed the following steps: weigh $7.5 \mathrm{~g}$ of thoroughly homogenized sample into a $50 \mathrm{~mL}$ centrifuge tube, then add $7.5 \mathrm{ml}$ acetonitrile, $0.75 \mathrm{ml}$ acetic acid, and $5 \mathrm{ml}$ hexane. Vortex the tube thoroughly for one min to solubilize/disperse the sample in hexane. Centrifuge the tube for 5 min at 3700 rpm using an RT6000B centrifuge from Sorvall. Subsequently, discard the hexane layer. The supernatant was transferred into a clean centrifuge tube and add $375 \mathrm{mg}$ of anhydrous Mg SO4 and $125 \mathrm{mg}$ of PSA. Immediately, seal the tube and shake vigorously for 30 seconds, and centrifuge at 3700 rpm for 5 min. The supernatant was evaporated by a vacuum rotary evaporator. The dry residue was reconstituted in $2 \mathrm{~mL}$ acetonitrile for HPLC analysis (Anastassiades et al., 2003).

The recovery experiment was performed by spiked $5 \mathrm{mg}$ of acrylamide standard to $7.5 \mathrm{mg}$ of thoroughly homogenized potato chips samples and extracted then dried. Then $10 \mathrm{~mL}$ of acetonitrile was added to reach a concentration of $100 \mu \mathrm{g} \mathrm{mL}^{-1}$. The percentage recoveries were calculated using the following equation: percentage of recovery $=\left[\mathrm{C}_{\mathrm{E}} / \mathrm{C}_{\mathrm{M}} \times\right.$ $100]$, where $C E$ is the practical concentration obtained from a standard solution of $100 \mu \mathrm{g}$ mL-1 of each compound in acetonitrile and $\mathrm{CM}$ is the spiked concentration after extraction (Chowdhury et al., 2012). 
Instrumentation (HPLC): The HPLC system consisted of Thermo Series P2000 Analytical Pump, The Series 200 Autosampler, Series 200 UV/Vis Detector (from 190 to $1000 \mathrm{~nm}$ ), and $20 \mu \mathrm{L}$ loop injector. The stationary phase represents the analytical column which was a Brownlee Bio C18 column of 250x4.6 mm and $5 \mu \mathrm{m}$ particle size.

HPLC operating conditions used Mobile Phase consisted of water containing $0.1 \%$ Formic acid (A) and acetonitrile (B), the flow

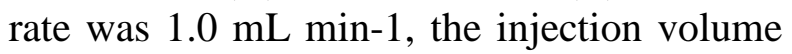
$20 \mu \mathrm{L}$, and it was detected at UV wavelengths of $200 \mathrm{~nm}$.

Statistical analysis: Data were analyzed using SPSS version 25 software. Statistical differences were tested using one-way ANOVA. Differences were considered significant at $\mathrm{p}$ values $\leq 0.05$ and then Tukey HSD analysis (Honest Significant Difference) was performed to determine whether there were statistically significant differences at $p$ values $\leq$ 0.05 between the concentrations of the different samples.

\section{RESULTS AND DISCUSSION}

Validation method: To determine the linearity of the HPLC response, a standard solution of acrylamide was prepared as described. Good linear correlations were obtained between peak areas and concentration in the selected range of $2.5-20 \mu \mathrm{g} \mathrm{mL}^{-1}$. Characteristic parameters for regression equations and correlation coefficients are given in (Table 1). The linearity of the calibration curve was validated by the high value of correlation coefficients of the regression graph.

A peak tailing (As 1.01) was being observed in chromatograms of acrylamide at all concentrations analyzed. Calibration standards were prepared and then demonstrated a linear response $\left(\mathrm{R}^{2}=0.999\right)$ over a $2.5-20 \mu \mathrm{g}$ $\mathrm{mL}^{-1}$. The limits of detection and quantification were determined to be 0.41 and $1.25 \mu \mathrm{g}$ (C) 2021 The Author(s). This open access article is distributed under a CC BY-NC 4.0 license. ISSN: online 2617-2186 print 2617-2178
$\mathrm{mL}^{-1}$ for acrylamide respectively, which is considered quite sensitive in comparison with most of the previous methods.

Intra-day precisions were determined using five concentration levels. The data showed that the method provided high levels of precision when used by the same analyst on the same day. Thus, the precision of the proposed method was determined by running calibration series solutions at $2.5-20 \mu \mathrm{gml}^{-1}$ and then was evaluated in terms of repeatability and expressed as the relative standard deviation (RSD, \%). The result of precision was ranged between 0.45 and $1.79 \%$, indicating good repeatability. All validation parameters for acrylamide are summarized in Table 1.

Table: (1). Summary of validation data for the quantification of acrylamide.

\begin{tabular}{cc}
\hline \hline Parameter & Acrylamide \\
\hline $\mathrm{t}_{\mathrm{R}}(\mathrm{min})\left(\mathrm{t}^{0}=1.95 \mathrm{~min}^{\mathrm{a}}\right)$ & 3.85 \\
Capacity factor $(\mathrm{k})$ & 0.17 \\
Symmetry factor $\left(\mathrm{A}_{\mathrm{s}}\right)$ & 1.01 \\
LOD $\left(\mu \mathrm{g} \mathrm{mL}^{-1}\right)$ & 0.41 \\
LOQ $\left.(\mu \mathrm{g} \mathrm{mL})^{-1}\right)$ & 1.25 \\
$\mathrm{~N}$ (plates) & 246.94(987.76) $\mathrm{N} \mathrm{ex-}$ \\
& pressed in plates per me- \\
Coefficient of regression & $0.999(\mathrm{y}=209459 \mathrm{x}-$ \\
$\left(\mathrm{R}^{2}\right)$ & $93643)$ \\
Precision $\left(\% \mathrm{RSD}^{-}\right) \mathrm{N}=3$ & 0.45 \\
$20 \mu \mathrm{gmL}^{-1}$ & 0.96 \\
$15 \mu \mathrm{g} \mathrm{mL}^{-1}$ & 1.79 \\
$10 \mu \mathrm{g} \mathrm{mL}^{-1}$ & 0.34 \\
$5.0 \mu \mathrm{g} \mathrm{mL}^{-1}$ & 1.42 \\
$2.5 \mu \mathrm{g} \mathrm{mL}^{-1}$ & \\
\hline \hline
\end{tabular}

Accuracy of the proposed method was also determined, the results indicated that the accuracy of the method performed in triplicate using $20 \mu \mathrm{g} \mathrm{mL}^{-1}$ concentration level, showed that in most cases, the recoveries of acrylamide ranged from $89.05 \%$ to $92.13 \%$, with RSDs less than $2.50 \%$ for the sample extraction procedure. Chromatogram of overlapped six concentration series obtained at the desired retention time is shown in Figure: 1. 


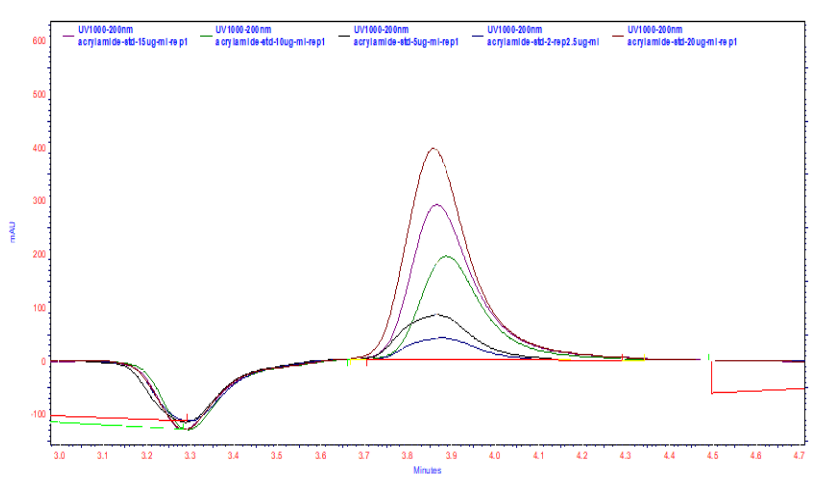

Figure: (1). HPLC chromatograms of acrylamide standards at wavelengths of $200 \mathrm{~nm}$ were 2.5;5.0; $10 ; 15 ; 20 \mu \mathrm{g} \mathrm{mL}-1$

\section{Quantification of Acrylamide in selected potato chips and French fries: The validat-} ed method of acrylamide was applied to analyze six food items include potato chips and French fries (Table 2). qualitative analysis of acrylamide content with HPLC was done by comparing the retention time of acrylamide standard at $20 \mathrm{ug} / \mathrm{mL}$ with samples, using the simplified sample treatment procedure, without the SPE step, it was possible to identify and determine acrylamide without overlapping between acrylamide peak and the overlapping compounds and produced minimum interfering peaks at the UV wavelength (200 nm) detection.

The regression equation of linearity was used to calculate the concentration of extracted samples, and five standards were prepared to build the calibration curve that was varied according to the expected level of acrylamide in food samples. All the analyzed samples have returned a positive level of acrylamide content. The Tiger brand was found to have the highest concentration of acrylamide when compared with the other potato chips products selected from the Libyan market with a statistically significant difference $(p<0.001)$ in comparison with other brands, whereas the Doritos brand showed the lowest concentration. The qualitative analysis of acrylamide content with HPLC was done by comparing the retention time of acrylamide standard at $20 \mu \mathrm{gmL}^{-1}$ with sample retention times. The qualitative analysis of acrylamide was analyzed by HPLC-UV. After validation and standard calibration series were carried out, the analysis of six products collected from the Libyan local market was performed. Results of acrylamide analysis showed the presence of a significant amount of acrylamide in all samples analyzed with different ranges (Table2). There was a statistically significant difference at the $\mathrm{p} \leq .05$ level within the levels of acrylamide for the samples. This strongly shows the presence of acrylamide in the samples. The results indicate that acrylamide was detected in all samples, but its concentration varied significantly from (2.85 -16.33 ppm). The statistical analysis indicated that the concentration of acrylamide in selected samples was positive and significant $(p<0.001)$. Data have shown that the acrylamide levels significantly differed among the brands. All the samples had acrylamide concentrations high acrylamide content above the permissible limits.

Table: 2. Acrylamide content in foods selected from Libyan market using HPLC-UV

\begin{tabular}{cc}
\hline \hline Product Name & $\begin{array}{l}\text { Acrylamide } \\
\text { Contents }\end{array}$ \\
\hline $\begin{array}{c}\text { Pringles sour cream and onion } \\
\text { (Poland) }\end{array}$ & $4.65 \mathrm{ppm}$ \\
$\begin{array}{c}\text { (Egypt) } \\
\text { Tiger } \\
\text { (Egypt) }\end{array}$ & $2.85 \mathrm{ppm}$ \\
$\begin{array}{c}\text { Lay's with chili and lemon } \\
\text { flavor } \\
\text { (Egypt) } \\
\text { Mr. Crunch ketchup } \\
\text { (Libya) } \\
\text { French fries }\end{array}$ & $16.33 \mathrm{ppm}$ \\
\hline \hline
\end{tabular}

In the present study, the acrylamide quantity of the potato chips of different brands and French fries ingested in humans was determined. The data shows that the tested brands contain a relatively high level of acrylamide. The highest level was about $1104 \mu \mathrm{g} / 66 \mathrm{~g}$ detected in the Tiger brand, followed by French fries $627 \mu \mathrm{g} / 60 \mathrm{~g}$, then Lays $301 \mu \mathrm{g} / 43 \mathrm{~g}, \mathrm{Mr}$ crunch $210 \mu \mathrm{g} / 65 \mathrm{~g}$, Pringles 185/40g, and the lowest was Doritos with $89 \mu \mathrm{g} / 32 \mathrm{~g}$ (Figure 2). 
The most recent toxicological data and exposure levels estimated the average human exposure at $1 \mu \mathrm{g} / \mathrm{kg}$ of body weight /day, with high-intake consumers at $4 \mu \mathrm{g} / \mathrm{kg}$ of body weight/ day (Fuhr et al., 2006). In light of this data, there is a clear hazard of acrylamide from long-time exposure, particularly with young age people, who are more attracted to chips and fries and ingest a high amount on a daily basis. Moreover, acrylamide can be found in most daily diet products such as baked food, cornflakes, and coffee, which increases the chance of more exposure and also, toxicity. With acrylamide, there is no doubt about the existence of a hazard. The International Agency for Research on Cancer of the WHO has evaluated acrylamide as possibly carcinogenic to humans (Stadler and Scholz, 2004). In view of these results, the consumption of acrylamide in the diet should be controlled to limit its hazards to human health.

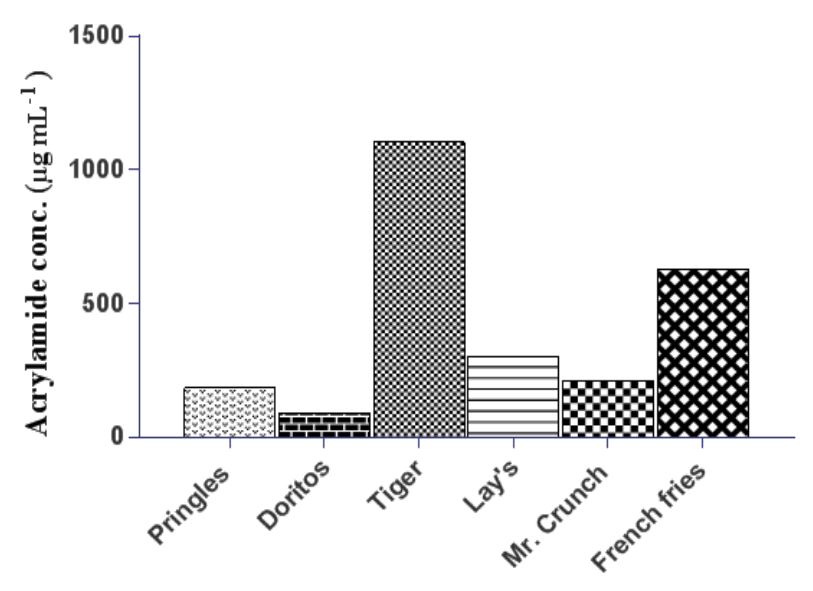

Figure: (2). Concentration of acrylamide per small package unit of selected brands that are marketed in the local Libyan market.

\section{CONCLUSION}

A quantitative HPLC-UV method has been developed which is rapid, sensitive, and reproducible. HPLC-UV is a method for the analysis of acrylamide in potato chips and French fries from the Libyan market using a simple sample preparation procedure. The LOQ and LOD were $1.25 \mu \mathrm{gmL}^{-1}$ and 0.41 method was successfully applied for the determination of acrylamide content of six potato chips and French fries products. Moreover, sample preparation comprising simplified extraction provides an effective and simple method to extract acrylamide and remove most oily substances in samples before HPLC analysis. Validation results reveal that this method is suitable for routine analysis of acrylamide residues in food products at low levels because detection and quantitation limits in the low concentrations and excellent repeatability were shown.

More measures should be made to lower and control the level of acrylamide in food items, especially in those consumed by susceptible groups such as children, young adults, and pregnant women.

\section{ACKNOWLEDGEMENT}

The authors would like to thank the Dean of the Faculty of Veterinary Medicine, the Head of the Department of Basic Medical Veterinary Sciences for the facilities provided and help rendered during the study.

\section{REFERENCES}

Altunay, N., Gurkan, R., \& Orhan, U. (2016, Dec 1). A preconcentration method for indirect determination of acrylamide from chips, crackers and cereal-based baby foods using flame atomic absorption spectrometry. Talanta, 161, 143-150.

https://doi.org/10.1016/j.talanta.2016.08 .053

Binet, S., Bru, K., Klinka, T., Touze, S., \& Motelica-Heino, M. (2015, May). Water and acrylamide monomer transfer rates from a settling basin to groundwaters. Environ Sci Pollut Res Int, 22(9), 6431-6439. 
https://doi.org/10.1007/s11356-0143106-2

Bull, R. J., Robinson, M., Laurie, R. D., Stoner, G. D., Greisiger, E., Meier, J. R., \& Stober, J. (1984, Jan). Carcinogenic effects of acrylamide in Sencar and A/J mice. Cancer Res, 44(1), 107-111. http://www.ncbi.nlm.nih.gov/pubmed/6 $\underline{360343}$

Calbiani, F., Careri, M., Elviri, L., Mangia, A., \& Zagnon, I. (2019). Development and Single-Laboratory Validation of a Reversed-Phase Liquid Chromatography-Electrospray-Tandem Mass Spectrometry Method for Identification and Determination of Acrylamide in Foods. Journal of AOAC INTERNATIONAL, 87(1), 107-115. https://doi.org/10.1093/jaoac/87.1.107

Calleman, C. J., Wu, Y., He, F., Tian, G., Bergmark, E., Zhang, S., Deng, H., Wang, Y., Crofton, K. M., Fennell, T., \& et al. (1994, Jun). Relationships between biomarkers of exposure and neurological effects in a group of workers exposed to acrylamide. Toxicol Appl Pharmacol, 126(2), 361-371. https://doi.org/10.1006/taap.1994.1127

Can, N. O., \& Arli, G. (2014, 2014/04/03). ANALYSIS OF ACRYLAMIDE IN TRADITIONAL AND NONTRADITIONAL FOODS IN TURKEY USING HPLC-DAD WITH SPE CLEANUP. Journal of Liquid Chromatography \& Related Technologies, 37(6), 850-863. https://doi.org/10.1080/10826076.2012. $\underline{758148}$
Elbashir, A. A., Omar, M. M. A., Ibrahim, W. A. W., Schmitz, O. J., \& Aboul-Enein, H. Y. (2014, 2014/04/03). Acrylamide Analysis in Food by Liquid Chromatographic and Gas Chromatographic Methods. Critical Reviews in Analytical Chemistry, 44(2), 107-141.

https://doi.org/10.1080/10408347.2013. $\underline{829388}$

Fuhr, U., Boettcher, M. I., Kinzig-Schippers, M., Weyer, A., Jetter, A., Lazar, A., Taubert, D., Tomalik-Scharte, D., Pournara, P., Jakob, V., Harlfinger, S., Klaassen, T., Berkessel, A., Angerer, J., Sorgel, F., \& Schomig, E. (2006, Feb). Toxicokinetics of acrylamide in humans after ingestion of a defined dose in a test meal to improve risk assessment for acrylamide carcinogenicity. Cancer Epidemiol Biomarkers Prev, 15(2), 266-271. https://doi.org/10.1158/10559965.EPI-05-0647

Galuch, M. B., Magon, T. F. S., Silveira, R., Nicácio, A. E., Pizzo, J. S., Bonafe, E. G., Maldaner, L., Santos, O. O., \& Visentainer, J. V. (2019, 2019/06/01/). Determination of acrylamide in brewed coffee by dispersive liquid-liquid microextraction (DLLME) and ultraperformance liquid chromatography tandem mass spectrometry (UPLCMS/MS). Food Chemistry, 282, 120126.

https://doi.org/https://doi.org/10.1016/j. foodchem.2018.12.114

Gertz, C., \& Klostermann, S. (2002). Analysis of acrylamide and mechanisms of its formation in deep-fried products. European Journal of Lipid Science and Technology, 104(11), 762-771. https://doi.org/https://doi.org/10.1002/1 
438-9312(200211)104:11<762::AIDEJLT762>3.0.CO;2-R

Gokmen, V., Senyuva, H. Z., Acar, J., \& Sarioglu, K. (2005, Sep 23). Determination of acrylamide in potato chips and crisps by high-performance liquid chromatography. $J$ Chromatogr A, 1088(1-2), 193-199. https://doi.org/10.1016/j.chroma.2004.1 $\underline{0.094}$

Hartmann, E. C., Boettcher, M. I., Schettgen, T., Fromme, H., Drexler, H., \& Angerer, J. (2008, 2008/08/01). Hemoglobin Adducts and Mercapturic Acid Excretion of Acrylamide and Glycidamide in One Study Population. Journal of Agricultural and Food Chemistry, 56(15), 6061-6068. https://doi.org/10.1021/jf800277h

Kapp, C. (2002, Jul 6). WHO urges more research into acrylamide in food. Lancet, $\quad 360$ (9326), 64. https://doi.org/10.1016/S0140$\underline{6736(02) 09378-9}$

Khan, M. R., Alothman, Z. A., Naushad, M., Alomary, A. K., Alfadul, S. M., Alsohaimi, I. H., \& Algamdi, M. S. (2017, Feb 2). Occurrence of acrylamide carcinogen in Arabic coffee Qahwa, coffee and tea from Saudi Arabian market. Sci Rep, 7, 41995. https://doi.org/10.1038/srep41995

Konings, E. J., Baars, A., van Klaveren, J. D., Spanjer, M., Rensen, P., Hiemstra, M., Van Kooij, J., \& Peters, P. (2003). Acrylamide exposure from foods of the Dutch population and an assessment of the consequent risks. Food and
Chemical Toxicology, 41(11), 15691579.

Liu, R., Sobue, T., Kitamura, T., Kitamura, Y., Ishihara, J., Kotemori, A., Zha, L., Ikeda, S., Sawada, N., Iwasaki, M., Tsugane, S., \& of the, J. S. G. (2019, Sep). Dietary Acrylamide Intake and Risk of Esophageal, Gastric, and Colorectal Cancer: The Japan Public Health Center-Based Prospective Study. Cancer Epidemiol Biomarkers Prev, 28(9), 1461-1468. https://doi.org/10.1158/1055-9965.EPI$\underline{18-1259}$

Mojska, H., Gielecińska, I., Szponar, L., \& Ołtarzewski, M. (2010). Estimation of the dietary acrylamide exposure of the Polish population. Food and Chemical Toxicology, 48(8-9), 2090-2096.

Mottram, D. S., Wedzicha, B. L., \& Dodson, A. T. (2002, Oct 3). Acrylamide is formed in the Maillard reaction. Nature, 419(6906), 448-449. https://doi.org/10.1038/419448a

Muthaiah, P., Govindaswamy, A., Semwal, A., \& Sharma, G. K. (2018, 12/31). HPLCUV Quantitative Analysis of Acrylamide in Snack Foods of India. Defence Life Science Journal, 4, 45-54. https://doi.org/10.14429/dlsj.4.12190

Nemoto, S., Takatsuki, S., Sasaki, K., \& Maitani, T. (2002, Dec). Determination of acrylamide in foods by GC/MS using 13C-labeled acrylamide as an internal standard. Shokuhin Eiseigaku Zasshi, 43(6), 371-376. https://doi.org/10.3358/shokueishi.43.3 $\underline{71}$ 
Oroian, M., Amariei, S., \& Gutt, G. (2015, 2015/04/03). Acrylamide in Romanian food using HPLC-UV and a health risk assessment. Food Additives \& Contaminants: Part B, 8(2), 136-141. https://doi.org/10.1080/19393210.2015. $\underline{1010240}$

Pedersen, J. R., \& Olsson, J. O. (2003, Apr). Soxhlet extraction of acrylamide from potato chips. Analyst, 128(4), 332-334. https://doi.org/10.1039/b212623k

Robinson, M., Bull, R. J., Munch, J., \& Meier, J. (1984, Feb). Comparative carcinogenic and mutagenic activity of coal tar and petroleum asphalt paints used in potable water supply systems. $J$ Appl Toxicol, 4(1), 49-56. https://doi.org/10.1002/jat.2550040110

Rommens, C. M., Yan, H., Swords, K., Richael, C., \& Ye, J. (2008, Oct). Lowacrylamide French fries and potato chips. Plant Biotechnol J, 6(8), 843853. https://doi.org/10.1111/j.14677652.2008.00363.X

Sorgel, F., Weissenbacher, R., KinzigSchippers, M., Hofmann, A., Illauer, M., Skott, A., \& Landersdorfer, C. (2002). Acrylamide: increased concentrations in homemade food and first evidence of its variable absorption from food, variable metabolism and placental and breast milk transfer in humans. Chemotherapy, 48(6), 267274. https://doi.org/10.1159/000069715
449-467. https://doi.org/10.1111/j.17534887.2004.tb00018.x

Svensson, K., Abramsson, L., Becker, W., Glynn, A., Hellenäs, K.-E., Lind, Y., \& Rosen, J. (2003). Dietary intake of acrylamide in Sweden. Food and Chemical Toxicology, 41(11), 15811586.

Vainio, H. (2003). Acrylamide in heatprocessed foods--a carcinogen looking for human cancer? Eur J Epidemiol, 18(12), 1105-1106. https://doi.org/10.1023/b:ejep.00000066 $\underline{42.47761 .1 \mathrm{f}}$

Virk-Baker, M. K., Nagy, T. R., Barnes, S., \& Groopman, J. (2014). Dietary acrylamide and human cancer: a systematic review of literature. Nutrition and cancer, 66(5), 774-790.

Wenzl, T., De La Calle, M. B., \& Anklam, E. (2003). Analytical methods for the determination of acrylamide in food products: a review. Food Additives and Contaminants, 20(10), 885-902.

Stadler, R. H., \& Scholz, G. (2004, Dec). Acrylamide: an update on current knowledge in analysis, levels in food, mechanisms of formation, and potential strategies of control. Nutr Rev, 62(12), (C) 2021 The Author(s). This open access article is distributed under a CC BY-NC 4.0 license. ISSN: online 2617-2186 print 2617-2178 


\section{الكثف والتقدير الكمي لمستوى مادة الأكريلاميد السامة في رقائق البطاطس، والبطاطس المقلية المختارة HPLC-UV من السوق الليبي باستخدام طريقة}

أسامة إدريس خريط 1**، عبدالسلام فضيل الفويرس²، عبدالرحمن الجالى 1 ، أم كلثوم أحمد عبد الجليل 3

$$
\begin{aligned}
& \text { 1 قسم الأدوية والسهوم، كلبة الطب البيطري، جامعة عد المختار البيضاء، ليبيا }
\end{aligned}
$$

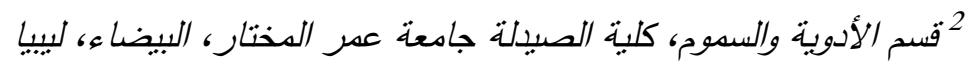

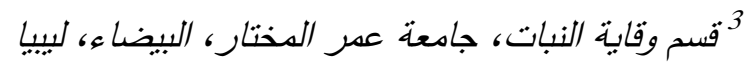

تاريخ الاستلام: 18 ديسمبر 2020 / تاريخ القبول: 15 أبريل 2021 https://doi.org/10.54172/mjsc.v36i2.39:Doi

المستخلص : مادة الأكريلاميد هي مركب ضار بالصحة ، يحدث في الأطعمة المخبوزة، والمقلية نتيجة التسخين الجاف المفرط

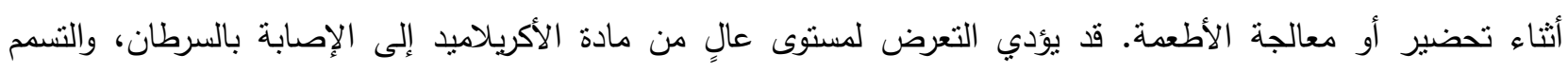

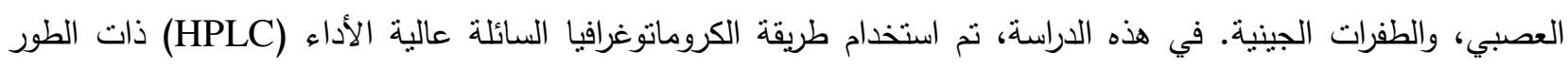

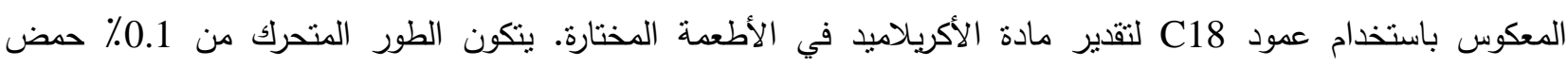
الفورميك في الماء: أسيتونيتريل (98:02)، ومعدل التدفق 1.0 مل/ دقيقة، نم الكثف عن طرديق الكاشف فوق البنفسجى عند طول موجى 200 نانومتر • أظهر التحقق من صحة الطريقة في الظروف المختارة أن الطريقة المختارة حساسة، وانتقائية، ودقيقة، وقابلة للتكرار مع استجابة خطية للكاشف لتحديد مادة الأكريلاميد. ونم تحقيق حد الكثف (LOD) عند 0.41 عندئ ميكروغرام /مل، و حد التقدير (LOQ) 1.25 ميكروغرام /مل على التوالي. تم تطبيق الطريقة المقترحة أيضًا بعد التحقق من صحتها على العلامات التجارية الستة الأكثر شيوعًا لرقائق البطاطس، والبطاطس المقلية في السوق الليبي. وتم استخلاص مادة الأكريلاميد بطريقة استخلاص مبسطة تتجنب التظظيف باستخلاص الطور الصلب (SPE)، ومن ثم تم تحليلها بواسطة ميث تم العثور على أعلى مستوى من مادة الأكريلاميد في علامة تجارية واحدة من رقائق البطاطس بنركيز 16.33 ميكروغرام/ مل، بينما أظهر منتج واحد فقط من منتجات البطاطس المقلية التي تم تحليلها تركيز أكريلاميد قدره 10.26 ميكروغرام /مل. الكلمات المفتاحية: أكريلاميد، سرطان، رقائق البطاطس، بطاطس مقلية، جهاز الكروماتوجرافي السائل عالي الأداء. 